\title{
Thyroid Gland Tissue
}

National Cancer Institute

\section{Source}

National Cancer Institute. Thyroid Gland Tissue. NCI Thesaurus. Code C33785.

The tissue that forms the thyroid gland. Its main component is the thyroid follicle. 